\title{
Optimizing the Use of Digital Technology in Building a Community Network of Consumption of Small and Medium Enterprises' Products during the COVID-19 Pandemic: The Case of Depok, Indonesia

\author{
Ichmi Yani Arinda Rohmah* \\ Universitas Nasional, Indonesia
}

\section{Andi Achdian \\ Universitas Nasional, Indonesia}

\begin{abstract}
The massive spread of the COVID-19 pandemic which started in the mid-2020 has had a significant impact on the sustainability of the production and marketing activities of goods and services by Small and Medium Enterprises (SMEs). In the context of Indonesia, the so-called policy Large Scale Social Restriction encourages small and mediumsized business groups to find strategic ways so that they can continue to carry out production and marketing activities. One of the strategic ways is building a network of people who consume goods by using digital technology. This study analyses the strategies of small and medium-sized business groups in building a community network of the consumption of small and medium-sized business products through digital technology during the COVID-19 pandemic with special reference to the case of Depok, in Indonesia. This is a descriptive qualitative study with interview, observation, and documentation techniques. The findings show that small and medium enterprises use several digital applications to be able to connect individuals to create a consumption group of "common taste" so that those small and mediumsized enterprises could maintain the continuity of selling their goods or products. As a result, this strategic method is proven to be quite beneficial for small and medium business groups.
\end{abstract}

\section{Key Words}

Digitization, network, consumption, SMEs, COVID-19

\footnotetext{
*Corresponding author:

Ichmi Yani Arinda Rohmah

Sociology Department, Universitas Nasional, Jalan Sawo Manila, No.61, Pejaten, Jakarta Selatan, Indonesia 12520

Email: ichmi@civitas.unas.ac.id
} 


\section{Introduction}

Like most countries in the world, the COVID-19 has been spreading in Indonesia since the first quarter of 2020. Due to the rapid spread of COVID-19, the Indonesian government has imposed regulations known as Large Scale Social Restrictions (Pembatasan Sosial Berskala Besar or PSBB), especially in areas that fell into the red zone category or the zone with the highest number of COVID-19 patients. The areas surrounding the capital city of Jakarta, Bogor, Depok, Tangerang, and Bekasi (Jabodetabek) experience the strictest measure of this regulation of Large Scale Social Restrictions.

The Large Scale Social Restrictions consist of a set of regulations that must be obeyed by people as follows:

1. People who work in workplaces or offices are required to temporarily work from home. Apart from office work, educational activities are also to be carried out from home;

2. Activities that are exempt from temporary suspension are government agencies, State/Regional Owned Enterprises, health, logistics, energy, communication and information technology, finance, hotels, construction, strategic industries, basic services, public utilities, industries that serve as objects of national vitality, daily needs, local and international organizations dealing with disasters and social;

3. All business activities that provide food and beverage service are not allowed to provide on-site services and must be accommodated from home, or using online services;

4. The hotel should provide services for people who would selfisolate and are not allowed to open service facilities that create crowds;

5. Public religious activities are conducted in limited ways and are advised to be carried out at home;

6. It is not allowed to carry out activities in public spaces with more than five people;

7. The operational hours of traditional and modern markets are all limited, namely: at traditional markets at 03:00 am-3:00 pm, retail traders and minimarkets at 08:00 am $-8: 00 \mathrm{pm}$, retail, wholesale, hypermarket, supermarket, minimarket, and convenience store at 10:00 am -09:00 pm; 
8. All social and cultural activities are temporarily suspended when Large Scale Social Restrictions are implemented;

9. Tourist attractions, entertainment, internet cafes, spas, massage parlours are temporarily suspended.

10. Religion-related gatherings such as weddings and funerals that are not due to COVID-19 are allowed. Circumcisions should be carried out at the health service provider's place and marriages can only be carried out at the Civil Registry Office or the Office of Religious Affairs; and

10. The operational hours and capacity of public and private transportation are limited. Public motorized vehicles and trains are only allowed to operate from 06 am to 6 pm (Dharmastuti 2020).

The regulations that apply to people during the implementation of the Large Scale Social Restrictions have a significant impact on the activities of Small and Medium Enterprises. Focusing on the case of Depok municipality in West Java province, this study chose three types of Small and Medium Enterprises as its research subjects, namely Small and Medium Enterprises that sell clothing, food, and masks. The Small and Medium Enterprise groups of clothing and food have been operating since before the COVID-19 pandemic while the Small and Medium Enterprise group of masks has been operating after the COVID-19 pandemic in 2020.

During the COVID-19 pandemic, the three groups of Small and Medium Enterprises have carried out new strategies in marketing their products. They surely needed new strategies as a form of adaptation to the implementation of the Large Scale Social Restrictions. Especially in marketing their products, they optimized the use of digital media which were considered quite effective tools by which the business groups can build a robust network with consumers within a relatively short time. They introduced their specific products in detail using digital media, either through e-commerce or Instagram platforms.

The small and medium business groups seemed to benefit from the background of most consumers, ranging from children to adults, who are accustomed to using digital media. Referring to statistical data submitted by the Indonesian Internet Service Providers Association (APJII) during the COVID-19 pandemic, internet users in Indonesia increased to $73.7 \%$ or 196.7 million from the total population of 266.9 million as recorded by the Central Statistics Agency of Indonesia (Elvira 2021). During the COVID-19 pandemic, ever since 2020, the Indonesian e-commerce association reports that there has been an increase in the number of 
Small and Medium Enterprises that utilize various types of marketplaces (Sukarno 2021).

This paper focuses its analysis on the use of digital technology in building a community network of consumers by Small and Medium Enterprises in Depok during the COVID-19 pandemic. The type of research method used is qualitative one that has the characteristics of proximity between researchers and research subjects. Here, a researcher is also the main instrument in research. The qualitative research method encourages researchers to do interpretation to social phenomena in society (Denzin and Lincoln 2009). The role of researchers in qualitative research is therefore substantial in extracting data in the field.

The subjects of this research were the Small and Medium Enterprise groups that produce clothing, masks, and food commodities during the covid-19 pandemic. This selection was based on preliminary observation, which showed that the three business groups experienced operational changes in running their businesses, especially in the process of selling and distributing goods to the consumers.

This qualitative study uses non-participant observation, open, structured and unstructured interviews, and documentation. We made observations on the operational activities of the Small and Medium Enterprises groups that produce clothing, food, and masks. We examined how the Small and Medium Enterprise groups utilized digital technology and marketplace applications. Then we also interviewed and documented the use of digital technology by the groups in their way to build consumers networks.

In checking the validity of the data in this qualitative research, we used triangulation of sources and methods. Source triangulation was used to check the validity of the information data obtained by comparing information from several informants. The triangulation of methods or $/$ techniques used to check the validity of the information data by comparing the data obtained using several methods, namely interviews, observation, and documentation (Sugiyono 2013).

In data analysis, we used the analytical model from Miles and Huberman (1984), namely (1) data collection, (2) data reduction, (3) data display, and (4) drawing conclusions and verification (Sugiyono 2013). $\mathrm{We}+$ carried out qualitative data analysis repeatedly while extracting data in the field. 


\section{The Operational Activities of Small and Medium Business during the COVID-19 Pandemic}

During the COVID-19 pandemic, the operational activities of Small and Medium Enterprises underwent significant changes. Before the pandemic, small and medium-sized businesses used marketing strategies for goods sold traditionally, namely through direct buying and selling, where business actors met directly with consumers to offer their goods. Everything changed when the COVID-19 pandemic hit the world. Business actors were compelled to use e-commerce and social media applications such as Instagram and WhatsApp as the last resort.

During the COVID-19 pandemic, the small and medium businesses have more opportunities to market goods than before the pandemic. During the pandemic, the business expenditure used for marketing strategies, which was not cost-sensitive, is now relatively small. Small and medium business actors, the subjects of this research, felt it on their side. Therefore, they market their product using digital technology to offer varieties of services or goods to consumers. Opportunities to get more consumers through digital technology were also wide open. These small and medium business actors could now see the characteristic of their consumers during the pandemic.

They observed that these consumers did many things using the internet, so they could be the premier target of marketing. Through this platform, they thought they were able to aim at consumers of various ages, ranging from teenagers to adults. Consumers from all walks of life, from various professions and occupations such as homemakers, office workers, schoolchildren and students, are marketing targets.

The price of goods offered through this platform become relatively accessible to many consumers. Making purchases now was without fuss; not to be bothered with various transaction terms, even without requiring them to leave the house. The customers only picked products that suit their needs or desires. This made selling goods through digital technology grow rapidly.

The buying and selling goods to consumers in such new and different ways encouraged consumers to innovate and create new things using the platforms of digital technology. In addition, manufacturers could establish relationships with other manufacturers to establish business cooperation. Figure 1 shows the transformation of business activities carried out by small and medium-sized businesses before and after the COVID-19 pandemic. 


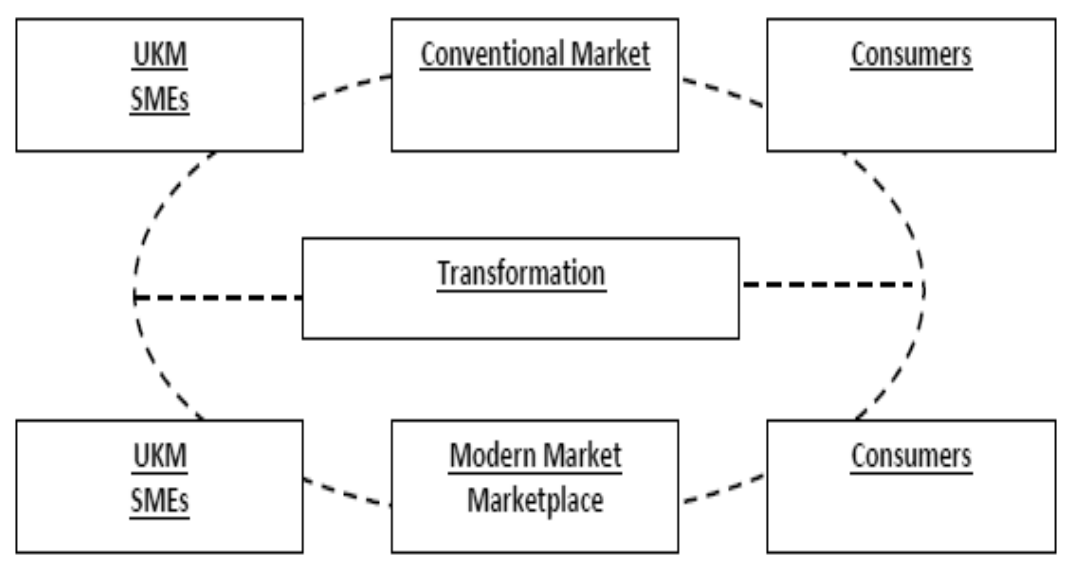

Figure 1. The Transformation of Small and Medium Business Activities before and after the COVID-19 Pandemic

In Figure 1, we see that before the COVID-19 pandemic, small and medium business actors did business, especially in buying and selling goods, through conventional markets. Business actors met their consumers at conventional market locations. In contrast, after the COVID-19 pandemic, business actors sold goods to their consumers through digital markets or known as digital marketplaces. Business actors and their consumers did not need to meet in person to make transactions. Both simply used digital technology to do business transactions.

The operational activities in utilizing the technology of buying and selling goods took into account the form of trust built for their consumers. Trust is one of the elements of social capital to build relationships and networks between individuals and others, individuals with groups, and between groups (Dwiningrum 2014). The phenomenon of social transformation in the digital era gave a sign that trust between individuals become easy to form. We see this from the behaviour of consumers who trusted their sellers to buy goods without having to meet them in person.

\section{Optimizing the Use of Digital Technology for Business}

Technological innovation in the economic field cannot be separated from the needs of market players: producers, distributors, and consumers (Smelser and Swedberg 2005). During the COVID-19 pandemic, especially when the Government of Indonesia declared a state of emergency due to the 
spread and transmission of COVID-19 in almost all parts of Indonesia, the Central Government and Regional Governments in the red zone areas including Depok City imposed the rules of Large Scale Social Restrictions (PSBB). This state of emergency had a significant impact on various fields including the economic sector. This prompts the need for efforts to help the economic market to survive in these difficult times.

Heeding to its people's predicament, the Indonesian government has made various efforts to keep businesses running. For example, the establishment of an online platform integrated into traditional markets. This was to sustain various types of innovations, which provided virtual market space or often referred to as a marketplace, following their initiations before the pandemic. Therefore, the market players were able to get new solutions to keep optimizing the operational activities of their small and medium businesses.

Through various types of marketplaces on e-commerce and social media applications, small and medium business actors were able to connect easily with their consumers and fellow business actors. Even during the pandemic, relationships were easy to build among resellers and distributors. So was between business actors who sold goods from other business actors. In e-commerce applications, business actors could cooperate and easily find the preferred-market prices of various goods so that a reference of prices could help to make decisions and to determine the right price of goods offered to consumers.

Another phenomenon that we found in the relationship between small business actors in the marketplace was that competition between business actors in the marketplace would easily occur, ranging from the types of commodities to the selling price of goods to consumers. This is what we perceive as a perfectly competitive market.

The efforts that were made to optimize the use of digital technology to maximize their operational activities were as follows: 1) Giving an attractive name for the online store; 2) Using product brands that are easily recognized by consumers; 3) Designing an online shop window to be attractive; 4) Giving discounts to certain commodities, and 5) Providing merchandise on several occasions so that consumers are interested in visiting online shops for business actors.

Apart from fulfilling their needs, most of the consumers were also attracted to visit the online shops due to the above-mentioned five efforts made by business actors. The consumers satisfied with the services of business actors and the goods they bought would make more purchases. 
In addition, these satisfied consumers would provide a good response and assessment that supported these business actors to grow.

\section{The Network of Small-Medium Business Consumers during the COVID-19 Pandemic}

Barry Wellman (1983) describes that a network always emphasizes to heed the regularity and maintain collectivity formed between individuals and groups. His analysis also identifies the patterns of ties that link these actors within a social structure. There are five characteristics of the formation of social networks described by Barry Wellman (1983 in Ritzer [2014]) as seen in Figure 2 as follows:

1. The symmetrical nature of the bond that connects the actors provides a reciprocal relationship and provides mutual support;

2. Individual bonds in the context of macro-network structure;

3. Non-random network formation;

4. The existence of groups in networks can produce relationships across groups and between individuals; and

5. Asymmetric bonds in a system can result in a different distribution of resources.

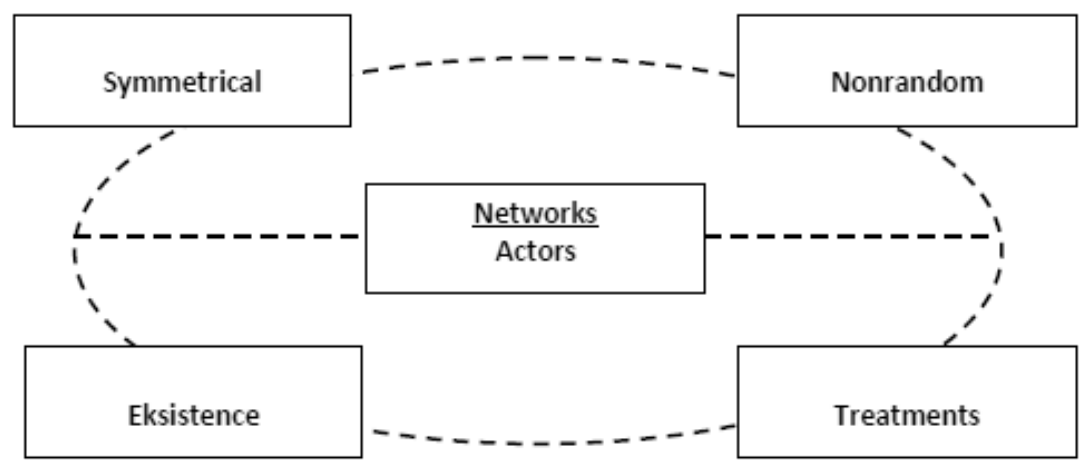

Figure 2. Formation of Social Networks (adapted from Wellman [1983])

Consumer networks in small and medium enterprises were easily identified by using indicators of network theory from Barry Wellman. The symmetrical nature of the bond that connects producers and consumers in the marketplace had a reciprocal relationship. Business actors in building initial networks with consumers used several strategies, namely at the beginning of opening a business by building a network with consumers who 
have personal and emotional closeness such as friends, family, and work environment. Then business actors built networks with foreign consumers who had no personal relationship. Many foreign consumers could easily track their orders through e-commerce applications.

The reciprocal relationship that occurred between business actors and consumers may take different forms. This symmetrical reciprocal consumer relationship can be easily identified through the network formed through several e-commerce application tools. These tools include as follows:

1. Assessment tool or evaluation;

2. Evaluation of business services and goods purchased by consumers;

3. Commentary tools that can be filled out by consumers;

4. Tool for signs of liking the products and services of business actors, storefront link;

5. Storage tool from online stores;

6. Question and answer tool between consumers and business actors;

7. Discussion and communication tool between consumers and business owners; between business owners, and between consumers; and

8. Then there is also a follower tool.

Consumers who felt satisfied with the services provided by business actors and are satisfied with the goods purchased gave a good response to online shop owners. The response was required in several forms: commenting or reviewing of satisfaction on the purchase of goods, giving a rating, following the online shop, adding items and closing their purchase at the last minute with the exact amount or multiplied.

In the context of the macro network, it can be identified in the relationships that were built between business actors and e-commerce companies, relationships between business actors, relationships between consumers, and relationships between business actors and consumers. The macro network could form cross-network with various groups of business actors and consumers. Networks that are not random (non-random networks) can be seen in the homogeneous types of consumers. For example, there was a consumer network from a socialite housewife environment, which was seen in the type of commodity they needed and in the number of purchases at certain times. Another was the consumer network of teenagers who were pursuing higher education had homogeneous characteristics in determining the type of commodity and the number of goods needed in a certain period. 
The existence of groups of business actors in the market was needed to increase the attractiveness of consumer groups or individuals. The strategy taken by the business groups to exist was to design an online storefront that looked attractive, use product brands that sufficiently increased consumer interest, and provide discounts on goods offered to consumers.

In addition to symmetrical network bonds, there were asymmetrical network bonds. Asymmetric bonds in the context of this study were often found in the bonds formed between business actors and foreign consumers or consumers without any emotional and personal ties. The asymmetric bonds were characterized by the behaviour of consumers themselves. Usually, consumers in asymmetric bonds only made purchases of goods once or rarely bought goods at the same online store, and these consumers were not active in providing or ratings and reviews of the services provided by the actors, businesses and goods purchased. This asymmetric bond also affected the special treatment given by business actors to their consumers. In asymmetrical ties, business actors rarely gave bonuses and discounts on the prices of goods offered to consumers.

The use of new digital technology innovations that create virtual spaces for economic actors was a form of effort to maintain community economic resilience, especially at the microeconomic level, which comprises many small and medium businesses. Nevertheless, there were still things less optimal and new problems arose in this digital technology-based economic activity. So, attention and solutions from many parties should be put here from digital economic technology developers, e-commerce companies, business people, both micro and macro, consumers, and the government as policymakers and supervisors of economic activities in digital spaces (marketplaces). Several problems were still there such as the lack of protection of consumer rights, protection of personal data of market players from producers to consumers, frauds and crimes experienced by consumers. We may add that there are groups of business actors whose understanding of the use of digital economic technology is still low. This particular segment of the digital marketplace needs to receive digital technology education.

\section{Conclusion}

This article has shown that during the COVID-19 pandemic, the community's dependence on digital technology to meet their needs is increasing as seen in the case of the Small and Medium Enterprises Groups in Depok. The 
Small and Medium Enterprise Groups saw a great opportunity to sell various products and services through digital technology. The types of digital technology widely used by Small and Medium Enterprise groups were marketplace applications and social media such as Instagram. The Small and Medium Enterprise Groups made a new strategy in building a consumer network using digital technology; it proved quite effective and profitable for the Small and Medium Enterprise Groups. Although there was a Large Scale Social Restriction regulation enforced from early 2020 to mid-2021 and then continued with the Enforcement of Community Activity Restrictions, the COVID-19 pandemic did not weaken the Small and Medium Enterprises Groups in running their business.

\section{Acknowledgement}

Thanks to the $1^{\text {st }}$ Bandung International Conference on Social Science: Contemporary Issues and Trends in Social Sciences in the Era of the Internet of Things, Bandung, 6-8 July 2021.

\section{References}

"APJII: Pandemi COVID-19 Buat Pengguna Internet di Indonesia Meningkat Hampir 200 Juta." VOI, November 10, 2020. Retrieved July 7, 2021 from (https://voi.id/teknologi/19331/ apjii-pandemi-covid-19-buat-pengguna-internet-di-indonesiameningkat-hampir-200-juta).

Denzin, Norman K. and Yvonna S. Lincoln. 2009. Handbook of Qualitative Research. Yogyakarta: Pustaka Pelajar.

Dhamastuti, Hestiana. 2020. "Catat! Ini Daftar Aturan PSBB di Bogor, Depok dan Bekasi yang Berlaku Hari Ini." DetikNews, April 15. Retrieved July 6, 2021 from (https://news.detik.com/ berita/d-4977383/catat-ini-daftar-aturan-psbb-di-bogor-depokdan-bekasi-yang-berlaku-hari-ini/3).

Dwiningrum, Siti Irene Astuti. 2014. Modal Sosial dalam Pengembangan Pendidikan (Perspektif Teori dan Praktik). Yogyakarta: UNY Press.

Ritzer, George. 2014. Teori Sosiologi: Dari Sosiologi Klasik sampai Perkembangan Terakhir Postmodern. Sleman: Pustaka Pelajar. 
Smelser, Neil J. and Richard Swedberg (Eds.). 2005. The Handbook of Economic Sociology. Princeton: Princeton University Press.

Sugiyono. 2013. Metode Penelitian Kuantitatif, Kualitatif, dan R\&D. Yogyakarta: Alfabeta.

Sukarno, P. A. 2021. "Ada Pandemi, Jumlah Transaksi dan Pelaku UMKM di e-Commerce Melesat". Ekonomi Bisnis 29 April 2021. 